\title{
Activities of the South African Museum.
}

$\mathrm{N}$ the first report that he presents as director of the South African Museum, Cape Town, Dr. Leonard Gill insists on the need for more space. In spite of this the staff goes on collecting. An expedition was made to the Kaokoveld in South-West Africa, carrying previous work as far as Zesfontein, where lives the decaying remnant of the Topnaar Hottentots ; a further expedition was starting for the country north of Zesfontein, of which the natural history is almost unknown. Other expeditions were to Gordonia, between Upington and the border of SouthWest Africa, and to the Langebergen behind Swellendam, in continuation of the exploration of the mountain ranges in the south-west of the Cape Province. Various traces of early human occupation were also investigated. The whole report bears witness to activity in many directions in spite of crowding and the small number of the staff.

The output of the museum during the past year is represented by the issue of six parts of the Annals of the South African Museum. The old-established plan by which the papers are classified more or less strictly into homogeneous volumes (botanical, geological, entomological, etc.) is awkward in that it keeps so many volumes open for rather long periods, but it is decidedly convenient when once the volumes are finished and bound. The large amount of the year's work refers to South-West Africa (the former German territory), which is explained by the fact that a number of expeditions from the Museum have been at work in that territory in recent years. They have gone there by special invitation of the local Administration and with the aid of grants from it-an unusual example of enlightenment which deserves recognition. We are informed that several further papers on the flora and fauna of South-West Africa are already in type. Considering the fewness of their numbers, the amount of scientific work turned out by the members of the Museum staff themselves is noteworthy. It is in part due to the fact that the Museum itself is still awaiting its urgently needed extensions. Thus 'gallery work' is largely paralysed - a bad thing for the public, though it allows the staff more time than they would otherwise have for research.

Thanks mainly to the persistence and energy of Dr. J. D. F. Gilchrist, our knowledge of the marine fishes of South Africa, which was very inadequate some thirty years ago, is now approaching completion in regard to the characters of the species and their distribution. At the beginning of the century a survey of the shallower waters, up to 50 fathoms, of the Cape seas, succeeded in bringing to light many new forms, and also in discovering new fishing grounds. During the last five years a further survey has been carried out on a larger scale, its operations extending to Natal and including the deeper waters. Large collections from Natal made by Dr. Warren in 1906 , and more recently by Messrs. Romer Robinson and H. W. Bell Marley, have been sent to the British Museum (Natural History) and have been described.

The present is an appropriate time for the results obtained to be brought together, and $\mathrm{Mr}$. K. H. Barnard's memoir (Annals of the South African Museum, vol. 2I, Pt. I, "A Monograph on the Marine Fishes of South Africa, Part I ") should be of considerable service to ichthyologists and others interested in the fish fauna of South Africa. The scope of the work is much wider than the title would suggest, as it includes not only the fishes of the coasts of the Union of South Africa, but also those of East and West Africa northwards to $15^{\circ} \mathrm{S}$., and oceanic fishes that have been recorded from within 200 to 300 miles of the east and west coasts and 400 miles southwards.

The fishes of Natal are mostly tropical, whereas those of the Cape are temperate and show Mediterranean affinities; we think that when Mr. Barnard comes to the perches, gobies, blennies, etc., which are so numerous in the Indo-Pacific region, he may regret that he has taken in the east coast northwards to Mozambique, and that only the fact that this area has not been too well explored will save his memoir from being overburdened with tropical species.

A number of papers enumerating and describing species belonging to various groups of S. African insects have been issued during the year. In a country so extensive as South Africa, animal life is abundant and of great interest, and we look forward to the time when the Government of that country will see its way to publish an authoritative "Fauna of South Africa." A model for such a work will be found in the "Fauna of India " series issued by the Secretary of State for India.

In vol. 19, Pt. 4, of the Annals of the South African Museum, 1925, Mr. L. B. Prout describes certain new species of Geometrid moths from material that has accumulated since his previous paper on the subject (Annals S.A. Museum, I9I7), two wellexecuted coloured plates accompanying this article. In the same part Mr. F. W. Edwards deals with a number of species of Mycetophilidæ and Bibionidæ contained in the Museum collections. The most interesting feature brought to notice is the discovery of a living species of Heterotricha, a genus which has only been previously known in a fossil condition contained in Baltic amber.

Part I of vol. 23 of the Annals of the Museum is devoted to an extensive illustrated memoir on the Hemiptera of South-West Africa by Dr. A. J. Hesse. It lists all the known species of Heteroptera and Homoptera from that region, excepting those belong. ing to the families Jassidæ, Aphididæ, and Coccidæ. The Hemiptera of South-West Africa have been little studied in the past, and it is perhaps not surprising that as a result of the Museum expeditions up to I924, together with the efforts of other collectors, II new genera and 58 new species are established. The most extensive additions pertain to the families Reduviidæ (3 new genera, II new species) and Fulgoridæ (5 new genera, I7 new species).

"Palæontological Papers published in conjunction with the Geological Survey" were added to the natural history publications of the South African Museum about a quarter of a century ago, thus extending their scope and usefulness. In the matter of the Mollusca, the non-marine early received attention, and if the papers have been few in number they have been important in matter. So early as I9oo, Mr. W. E. Collinge had two papers on the slugs of South Africa; while one whole big part was devoted in I9I2 to Major Connolly's valuable " Reference List of South African Non-marine Mollusca." This last was a piece of systematic work which has great value, on account of its carefully compiled synonymy and nomenclature, to others besides the immediate circle of those for whose benefit it was drawn up.

Lately another important molluscan paper, this time anatomical in character, has appeared (vol. 2o, Pt. 4) from the pen of that past master in molluscan anatomy, Mr. Hugh Watson. He deals with "The South African species of the Molluscan genus Onchidella," and in addition to their anatomy discusses 
their affinities with the species found in other parts of the world and the geographical distribution of the genus. Eight excellent plates from the author's pencil and camera, with their keys and a map, are appended in illustration.

A first contribution to "Reports on the Marine Mollusca in the Collections of the South African Museum," by J. R. Ie B. Tomlin, on the family Turritellidæ, accompanies the preceding. What it wants in length this paper makes up in importance. It is a purely systematic paper, but describes and illustrates two new species of Turritella, besides introducing a new term, "scalarescence," to denote a tendency to looser coiling sometimes exhibited in these shells. Conchologists will assuredly look forward to meeting with further such contributions in these Annals.

Vol. 22, Pt. I, of the Annals contains five papers on South African fossils and fossil woods. Africa, especially in its more central parts, is still in large measure the undiscovered land so far as its extinct animals are concerned. The veil has been lifted a little on its Mediterranean borders chiefly through the work of the late Dr. C. W. Andrews. On the east coast, where the remains of the largest forms of extinct reptiles have been discovered, there is possibility of great further discovery. In the south our knowledge is fuller and of longer standing, though even here it must be recognised that the known and described forms can be only the merest fraction of the animals that lived and evolved there, and exploration is far from being finished. In South Africa is the well-known Karroo series of formations, which are perhaps the most important centre of reptilian and amphibian evolution that has as yet been explored. The earlier classical works of Owen, Huxley and Seeley are, many of them, based on specimens from here. So are the more recent classics of Watson and Broom.

In reviewing the labours of various researchers in this field, the assistance rendered by the Trustees of the South African Museum and by the Geological Survey of South Africa must not be underestimated; the Annals of the South African Muserm contains many important papers on vertebrate palæontology by Broom and S. H. Haughton. A recent number contains the thirteenth paper by the latter author on extinct reptiles and amphibia of the district. The format of the publication, the typography, and the production of the plates are all excellent.

The grasses of Namaqualand, Damaraland, and Ovamboland are listed by Miss S. Garabedian (Annals, vol. I6, Pt. 2) ; representatives of most of them are now in the Herbarium of the South African Museum. It is hoped later to issue a list of the grasses of the mountainous country on the west called the Kaokoveld and the sand-dune belt between the mouths of the Orange and Cunene rivers, known as the Namib. Genera are arranged according to the key given by Dr. Stapf in the "Flora of Tropical Africa." Under the different species there are often notes as to the value of the grass as fodder, or its disadvantage as a weed in cultivation or as injurious to grazing stock.

\section{Experimental Investigation of Dengue.}

$\mathrm{W}$

HEN the Medical Research Board was organised for the Philippines in I922 at the recommendation of the Surgeon-General of the United States Army, the investigation of the etiology of dengue was one of the most important problems to be studied. Lieut.-Col. J. F. Siler, Majors M. W. Hall and A. P. Hitchins were appointed, and commenced their labours in I924 at Manilla, and in the Philippine Journal of Science of Jan.-Feb. (vol. 29, Nos. I-2, pp. $304+8$ plates) they describe their results.

The investigation was most carefully planned and most thoroughly carried out on the model of so many other etiological problems conducted by our American confrères. A very complete history of the disease is first given; the earliest accurate descriptions of dengue in epidemic form are from Cairo in 1779 , from Batavia and Java in I779, and from Philadelphia in I780, showing that then it was widely distributed, and it still remains so, but there is reason to believe that its original home was in tropical America. Compared with yellow fever, to which the disease has many etiological similarities, this world-wide diffusion is remarkable. Throughout these areas some of the epidemics are often classed as "dengue-like" rather than true dengue, but the authors, after most careful consideration, state that "it would appear that among themselves they differ little, if any more, than do different outbreaks of dengue, and until specific etiological evidence is available the possibility of their essential identity must be borne in mind."

The experiments detailed in this monograph were carried out in the Philippines, and were made on sixty-four American soldier volunteers to determine the transmission of dengue by means of mosquitoes : the men were in screened wards and the mosquitoes used were bred from the egg. In one hundred and eleven biting experiments made by infected females of $A$ ëdes aegypti (better known as Stegomyia fasciata), dengue was transmitted forty-seven times. ${ }^{1}$ All experiments with Culex fatigans were negative, thus not confirming the early and useful work by Graham. The filterable virus of the disease is present in the blood of the case only during the first three days of the fever, and requires at least eleven days to develop in the mosquito before it can be transmitted. The infectivity of the insect continues throughout its life but is not passed on to its progeny. It was found that $5^{8}$ per cent. of those who had suffered from the disease were immune, and in the others the course was modified. The rapidity of the spread of dengue is second only to influenza, but the diseases are not mutually protective.

The results brought out by the inquiry are in striking similarity with those observed in yellow fever, and strongly suggest some group relationship. Though so far in dengue the actual cause has not been definitely demonstrated, yet spirochætal forms have been reported for both. The authors were unable to transmit the infection to animals. From a practical point of view, the authors conclude that as dengue and yellow fever are transmitted by the same mosquito and the mechanism of transmission for each is almost identical, therefore epidemics of dengue and yellow fever are subject to the same control measures; the foremost of which is the reduction of the incriminating mosquito in the affected area; secondly, the protection of patients from mosquito bites during the first three days, by adequate mosquito nets, etc., during both day and night.

The previous work of other investigators is duly recognised and acknowledged, but the research here recorded is the most thorough and admirable on the subject.

1 Of the sixty-four volunteers used, dengue was produced experimentally in fifty-two, or $8 \mathrm{I}$ per cent. 